\title{
Arsenic data availability in agricultural soils and waters in Europe
}

\author{
T. Hatakka \& T. Tarvainen \\ Geological Survey of Finland, Espoo, Finland
}

\begin{abstract}
The AgriAs project - Evaluation and management of arsenic contamination in agricultural soil and water has compiled a summary of European-wide databases and publications on As concentrations in agricultural soils and related water bodies, As concentrations in crops together with a list of gaps in data and knowledge. The literature review and the AgriAs questionnaire revealed that there is a large amount of nationwide or large-scale data on arsenic concentrations in soil, surface water and/or groundwater from many countries. However, none of the countries has published regional maps of arsenic concentrations in crops. According to the literature review and the questionnaire, no national-scale data on As concentrations in groundwater, stream water, sediment or topsoil are available from Belgium, Denmark, Estonia, Greece, Latvia, Moldova and Romania. Moreover, there are no data from European-wide mapping programmes for two countries: Moldova and Turkey. There is no up-to-date map of arsenic concentrations in European groundwater related to agricultural sites. There are quite extensive European-wide datasets on As concentrations in agricultural soil, but more detailed regional mapping at the national level is needed, especially in those areas where anomalously high As concentrations in topsoil have been discovered. According to the AgriAs studies, European-wide data, as well as the nationwide data, on As concentrations in crops are almost completely lacking. The AgriAs project provides the European Union with reliable data on the existing risks of arsenic exposure through agriculture, a complete summary of existing tools available for As remediation as well as an array of tools for ecotoxicity and bioavailability assessment.
\end{abstract}

\section{INTRODUCTION}

Arsenic is a toxic and carcinogenic substance. According to $\mathrm{WHO}$, the greatest threat to public health from arsenic originates from contaminated groundwater. Food is another notable pathway for As exposure in humans. There are numerous arsenic-related publications and reports, but many of them focus on arsenic problems in South-East Asia or are limited to groundwater or contaminated soil. The AgriAs (Water-JPI 2017) project has focused on European data on agricultural soils and the quality of related surface water and groundwater.

\section{METHODS}

The AgriAs (http://projects.gtk.fi/AgriAs/index.html) Task Assessment of data availability on As concentrations in water, soil and crops in Europe has summarized European-wide databases and publications on As concentrations in soil and water. This was followed by a literature review and a questionnaire on nationallevel data sources of As concentrations in agricultural soil and water. A web-based AgriAs questionnaire on national and large-scale regional data sources on arsenic in soil, surface water, groundwater and crops in Europe was sent in May 2017 to 116 organizations from 23 countries. The selected organizations represented environmental authorities and research organizations working on water quality, (agricultural) soil and environmental issues. The general findings concerning As concentrations in crops were summarized from the literature. Following the assessment of data availability, a list of major data gaps was reported.

\section{RESULTS AND DISCUSSION}

The AgriAs project has concentrated on European publications, reports and data related to arsenic. Reimann et al. (2009) have provided a comprehensive summary of the European-wide availability of data on As concentrations in soil and water. More up-to-date information on national and regional data sources were identified from the AgriAs questionnaire. The questionnaire revealed that regional-scale data are available on arsenic concentrations in soil and surface water. These data can provide a detailed insight into the European-wide anomalies found in the FOREGS (Salminen et al., 2005), Baltic Soil Survey (Reimann et al., 2003), GEMAS (Reimann et al., 2015; Tarvainen et al., 2015) and LUCAS surveys (Tóth et al., 2015a, 2015b). The European-wide arsenic data availability is presented in Table 1. In addition, regional and national data are available on arsenic concentrations in groundwater, which have been lacking from the European-wide geochemical mapping programmes. Unfortunately, no publicly available 
Table 1. The European-wide arsenic data availability in the Water JPI member countries in Europe. SW $=$ Stream water, $\mathrm{SD}=$ Sediment, $\mathrm{TS}=$ Topsoil. The letters in bold indicate the maximum concentrations of As are relatively high (SW: As Max $>7 \mu \mathrm{g} \mathrm{L}^{-1}$, SD and TS: As Max $>25 \mathrm{mg} \mathrm{kg}^{-1}$, LUCAS TS: As Max $>50 \mathrm{mg} \mathrm{kg}^{-1}$ ). White $=$ no data available. FOREGS $=$ Geochemical Atlas of Europe (Salminen et al., 2005), BSS = Baltic Soil Survey (Reimann et al., 2003), GEMAS = Geochemistry of European agricultural and pasture soils (Reimann et al., 2015), LUCAS = Lucastopsoil survey (Toth et al., 2015a, 2015b).

\begin{tabular}{|c|c|c|c|c|}
\hline Country & $\begin{array}{l}\text { FOREGS } \\
\text { Agricultural } \\
\text { Soil } \\
\text { Catchments }\end{array}$ & BSS & $\begin{array}{l}\text { GEMAS } \\
\text { Agricultural } \\
\text { Soil }\end{array}$ & $\begin{array}{l}\text { LUCAS } \\
\text { Agricultural } \\
\text { Soil }\end{array}$ \\
\hline Austria & SW, SD, TS & & TS & TS \\
\hline Belgium & & & TS & TS \\
\hline Cyprus & & & TS & TS \\
\hline Denmark & & & TS & TS \\
\hline Estonia & $\mathrm{SW}, \mathrm{SD}, \mathrm{TS}$ & TS & TS & TS \\
\hline Finland & & TS & TS & TS \\
\hline France & SW, SD, TS & & TS & TS \\
\hline Germany & SW, SD, TS & TS & TS & TS \\
\hline Greece & & & TS & TS \\
\hline Hungary & SW, SD, TS & & TS & TS \\
\hline Ireland & & & TS & TS \\
\hline Italy & $\mathbf{S W}, \mathrm{SD}, \mathbf{T S}$ & & TS & TS \\
\hline $\begin{array}{l}\text { Latvia } \\
\text { Moldova }\end{array}$ & SW, SD, TS & TS & TS & $\mathrm{TS}$ \\
\hline $\begin{array}{l}\text { The } \\
\text { Netherland }\end{array}$ & & & TS & TS \\
\hline Norway & & TS & TS & TS \\
\hline Poland & $\mathrm{SW}, \mathrm{SD}, \mathrm{TS}$ & TS & TS & \\
\hline $\begin{array}{l}\text { Portugal } \\
\text { Romania }\end{array}$ & SW, SD, TS & & TS & $\begin{array}{l}\text { TS } \\
\text { TS }\end{array}$ \\
\hline Spain & $\mathbf{S W}, \mathrm{SD}, \mathbf{T S}$ & & TS & TS \\
\hline $\begin{array}{l}\text { Sweden } \\
\text { Turkey }\end{array}$ & & TS & TS & TS \\
\hline $\begin{array}{l}\text { United } \\
\text { Kingdom }\end{array}$ & SW, SD, TS & & TS & TS \\
\hline
\end{tabular}

national or regional datasets were reported on arsenic concentrations in crops.

According to the literature review and the questionnaire, no national-scale data on As concentrations in groundwater, stream water, sediment or topsoil are available from Belgium, Denmark, Estonia, Greece, Latvia, Moldova or Romania. There are no data from European-wide mapping programmes for two countries: Moldova and Turkey.

\section{CONCLUSIONS}

There are quite extensive European-wide datasets on As concentrations in agricultural soil, but more detailed regional mapping at the national level is needed, especially in those areas where anomalously high As concentrations in topsoil have been discovered. According the AgriAs questionnaire and literature study, European-wide data as well as nationwide data on As concentrations in crops are entirely lacking. There is no up-to-date map of arsenic concentrations in European groundwater related to agricultural sites. European-wide or large-scale regional databases very seldom combine arsenic concentrations in agricultural topsoil with concentrations in adjacent surface water or groundwater.

The AgriAs project provides the European Union with reliable data on the existing risks of arsenic exposure through agriculture, a complete summary of existing tools available for As remediation as well as an array of tools for ecotoxicity and bioavailability assessment.

\section{ACKNOWLEDGEMENTS}

AgriAs is co-funded by EU and the Academy of Finland, L'Agence Nationale de la Recherché (France), Bundesministerium für Ernährung und Landwirtschaft (Germany) and Forskningsrådet FORMAS (Sweden) under the ERA-NET Cofund WaterWorks2015 Call.

\section{REFERENCES}

Reimann, C., Siewers, U., Tarvainen, T., Bityukova, L., Eriksson, J., Gilucis, A., Gregorauskiene, V., Lukashev, V., Matinian, N.N. \& Pasieczna, A. 2003. Agricultural Soils in Northern Europe: A Geochemical Atlas. Geologisches Jahrbuch, Sonderhefte, Reihe D, Heft SD 5. Schweizerbart'sche Verlagsbuchhandlung, Stuttgart

Reimann, C., Matschullat, J., Birke, M. \& Salminen, R. 2009. Arsenic distribution in the environment: the effects of scale. Appl. Geochem. 24(7), 1147-1167.

Reimann, C., Birke, M., Demetriades, A., Filzmoser, P. \& O'Connor, P. (eds) 2015. Chemistry of Europe's Agricultural Soils. Part A: Methodology and Interpretation of the GEMAS Data Set. Geologisches Jahrbuch Reihe B Heft 102. Schweizerbart'sche Verlagsbuchhandlung, Stuttgart.

Salminen, R., Batista, M.J. \& Bidovec, M. 2005. Geochemical Atlas of Europe. Part 1 - Background Information, Methodology and Maps. Geological Survey of Finland, Espoo, Finland.

Tarvainen, T, Birke, M. \& Reimann, C. 2015. Arsenic anomalies in European agricultural and grazing land soil. pp. 81-88. In: C. Reimann, M. Birke, A. Demetriades, P. Filzmoser \& P. O'Connor (eds) Chemistry of Europe's Agricultural Soils. Part B: General Background Information and Further Analysis of the GEMAS Data Set. Geologisches Jahrbuch Reihe B Heft 103. Schweizerbart'sche Verlagsbuchhandlung, Stuttgart.

Tóth, G. Hermann, T., Szatmári, G. \& Pásztor, L. 2015a. Maps of heavy metals in the soils of the European Union and proposed priority areas for detailed assessment. Sci. Total Environ. 565: 1054-1062.

Tóth, G., Hermann, T., Da Silva, M.R. \& Montanarella, L. 2015b. Heavy metals in agricultural soils of the European Union with implications for food safety. Environ. Int. 88: 299-309.

Water-JPI. 2017. Water JPI, Challenges for a changing world. http://www.waterjpi.eu/index.php?option=com content\&view $=$ article\&id $=79 \&$ Itemid $=686$ 